\title{
Collaborative Consumption and Tourism: Online Travelers' Experience
}

\author{
Chiara Giachino*, Piergiorgio Re ${ }^{* *}$, Valter Cantino ${ }^{* * *}$
}

\begin{abstract}
Tourism came out to be one of the sector more involved in the sharing economy and in the collaborative consumption phenomenon: the way people choose, buy and live a journey is changed and, even the way to do tourism is changed.

Sharing and collaborative consumption, based on trading and swapping, has given the possibility to new companies to emerge and serve travelers as they need to. Today, lot of people doesn't know how to describe the collaborative consumption, but they use it in everyday life. Airbnb, Couchsurfing, HouseTrip and many others are examples of how collaborative consumption meets the tourist industry: different way to satisfy tourist's search for a solution. The aim of the research is to investigate the users' attitude toward online platforms and, how those platforms are changing travel's experience.
\end{abstract}

Keywords: Collaborative Consumption; Sharing Economy; Tourism; Travelers; Technology; Global Markets

\section{Sharing Economy and Tourism}

The sharing economy is a pretty recent phenomenon, in fact, the Oxford Dictionary introduced the word only during the 2015, describing it as "An economic system in which assets or services are shared between private individuals, either free or for a fee, typically by means of the Internet" (Maci, 2016). It is pretty difficult to find a unique definition of sharing economy in literature (Schor, 2016; Bernardi, 2015), but some studies define it as an economictechnological phenomenon based on information and communication technology that increases the awareness of consumers and, helps the creation of new webcommunities (Hamari et al., 2016; Wang \& Zang, 2012; Botsman \& Rogers, 2010).

Its main goal is to encourage the sharing-attitude and, to do this, two kind of providers are taking into consideration: peer to peer $(\mathrm{P} 2 \mathrm{P})$ and business to peer (B2P); there are also two kind of platform orientations: non-profit and for-profit (Schor, 2016).

Food Swaps, MakerSpace, Airbnb and Zipcar are just four of the thousand platforms which are included in the sharing economy and that create a new online market (Zervas et al., 2014).

\footnotetext{
* Assistant Professor of Management, University of Turin (chiara.giachino@unito.it)

** Full Professor of Management, University of Turin (piergiorgio.re@unito.it)

*** Full Professor of Management, University of Turin (valter.cantino@unito.it)
} Travelers' Experience, Symphonya. Emerging Issues in Management (symphonya.unimib.it), 3, 148-160. 
At the beginning, the main aim was to spread the sharing attitude only between peers $(\mathrm{P} 2 \mathrm{P})$, through the non-profit channel, but this phenomenon proved to be a really successful model. In fact, for-profit platforms and business to peer (B2P) providers, such as Airbnb and Zipcar, came out really quickly (Schor, 2016; Peeters et al, 2015).

Despite its recent origin this phenomenon is having a great success: studies report that the sector's revenues could reach $\$ 335$ billion globally by 2025 . The key elements that help the sharing economy success are the economics, socials, environmental and, technological factors (Peeters et al, 2015). Those four factors can be considered the main drivers for the development of this economic model based on sharing. In increasing the sharing effect around the world also the financial crisis - which is an economic factor - played a really relevant role, as much as the technological innovations and the Web 2.0 (Schor, 2016; Eckhard \& Bardini, 2015).

The sharing economy provided a really vast options of tourism services with the online platforms (Peeters et al, 2015; Eckhard \& Bardini, 2015). Hence, the sharing economy has created an alternative option, a better capacity to meet the demand, a higher level of value generated and a sort of expansion of markets. This opportunity is essential for tourism and its destinations that have to face with an always higher level of competition that is characterizing every sector (Brondoni, 2016). The globalization of markets has decreased the level of barriers and, knowledge together with ideas, are essential to compete and survive for companies (Brondoni, 2014; Brondoni, 2002).

\section{Collaborative Consumption's Changes}

The sharing economy is an umbrella under which different terms are collocated and, between them there is the collaborative consumption (Hamari et al., 2016).

The main difference between sharing economy and collaborative consumption is that the sharing economy is a really ample and wide concept focused on sharing underused assets, while collaborative consumption is more focused on the reinvention of traditional market behaviors (Botsman, 2015).

Ray Algar (2007) during an interview used the expression collaborative consumption, underlying how the consumers' power was strongly and quickly increasing. In a second moment, the concept gained a lot of notoriety thanks to Rachel Botsman that define this phenomenon using the expression "What's mine is yours" (Botsman \& Rogers, 2011).

To clarify the concept, three different way to practice the collaborative consumption are highlighted (Botsman, 2013):

- $\quad$ Product Service System (Pss): "pay to access the benefit of a product versus needing to own it outright".

- Collaborative Lifestyle: "non-product assets such as space, skills and money are exchanged and traded in new ways".

- Redistribution Markets: "unwanted or underused goods redistributed".

The collaborative consumption is based on an economic model of sharing, swapping, trading, or renting products and services, enabling access over ownership (Kade, 2015) and, the involvement of tourism industry lead people to choose, buy and live a journey is a different manner. 
Ideas such as sharing, lending, renting, gifting or swapping aren't an innovation themselves: home swapping, for example, has its origin in the 1950s in Great Britain and United States (Franco \& Garibaldi, 2015). The real innovation is their application through technology: it gives the chance to match millions of offers and millions of demands in few seconds. At first, collaborative consumption had some problems: many people thought it was "a nice idea about sharing small household stuff", they didn't get the potential, which is now pretty evident for anybody (Botsman, 2013).

\section{Tourists, Travelers and Empowerment}

Although the transformation of the tourism sector begins a lot of years ago, together with the increase of people education, wealth, and the infrastructure's improvements (Forno \& Garibaldi, 2015), collaborative consumption has speed up its transformation and, companies such as Airbnb and many others are examples of how collaborative consumption meets the tourism industry. The majority of people when is thinking about the tourism has clear in mind the traditional kind of tourism: the mass tourism. This is a kind of tourism that seems to restrict the freedom of lot of people (Arente \& Kiiski, 2006; Grit \& Linch, 2011), above all the youngest one.

During years, it became always more difficult to identify and categorized tourists' profile (Heath, 2011): if the traditional tourist is looking for relax and being a spectator of the travel (Franco \& Garibaldi, 2015), the new tourist is looking for something more deep and emotional. For this reason, some tourists prefer to customize their packages: they don't act anymore like tourists but like travelers. The new online platforms are helping people to organize their travels without the mediation of traditional agencies (Franch \& Martini, 2002). In fact, the technological element, together with the new tourist preferences, has modified the channel structure that normally tourist's suppliers were used to exploit (Pearce \& Schott, 2005), eliminating intermediary inefficiencies and redesigning markets (Salvioni, 2016). From this point of view, internet has a strong impact on the competitiveness of companies (Turban et al., 2000) and, it has become the channel through which suppliers give information and offer solution to customers. Internet provides companies with a way to offer their services directly to the consumer (De Carlos et al, 2016; Bloch \& Segev, 1996). In last years, consumers gained power and control over the consumption process: there has been a consumer empowerment (Hamari et al, 2016; Geyer-Schulz, A. \& Meyer-Waarden, 2014; Buhalis \& Law, 2008). Today, people that has to take a purchasing decision can follow the traditional purchase process or the collaborative process (Duffy, 2013).

Figure 1: Buyer Process Toward Collaborative and Purchase Decision

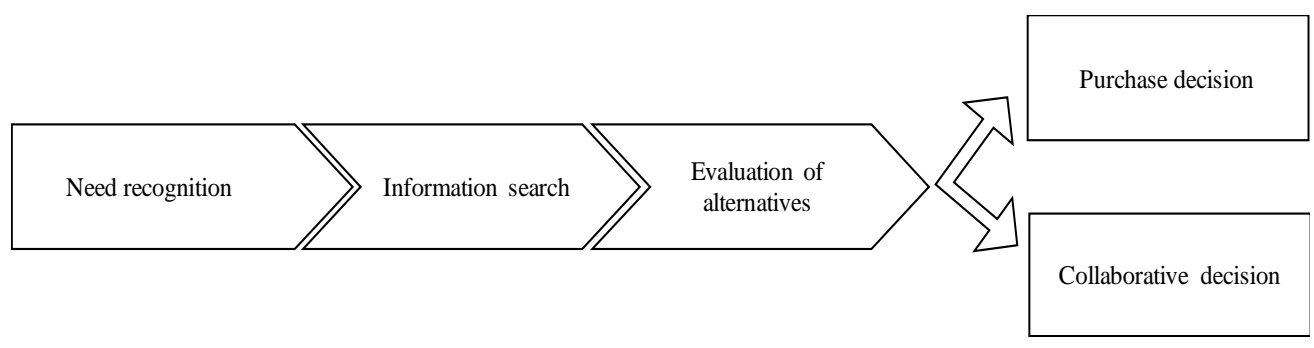

Source: authors' elaboration from Duffy (2013). 
The first three stages of the buyer decision process are in common between the two processes: need recognition, information search and alternatives' evaluation; traditionally those are followed by the purchase decision (Pellicelli, 2007). As a result of the empowerment process, customers can choose the collaborative decision over the purchase decision as ultimate step: renting Airbnb apartments rather than booking a hotel room or using car-sharing services rather than buying a car (Duffy, 2013). So, unlikely the traditional model, customers can choose to satisfy their needs just sharing assets and services, without the need to own something. The empowerment of the customer is mainly represented by the level of deeper information he/she can find on a specific topic, brand, companies and opportunities (Moltz, 2013). Companies have to deliver value to empowered customers to reach success (Brondoni \& Pironti, 2015).

\section{New Platforms and Services to Meet Traveler's Needs - Airbnb, Homeway, Housetrip, 9Flats, Couchsurfing}

Airbnb, Homeaway, Housetrip, 9Flats and Couchsurfing are online applications and websites, used by tourists to book an apartment or even just a room, based on the principle of sharing and renting. Those companies are the perfect example of how is changing the tourism (Ivanova, 2015) and, how companies create value for people. The founders of those platforms have identified and understand that travelers need an alternative to travel agencies, hotels, B\&B and hostels; a solution that let them travel saving money - and/or making new friends and experiences (Zbiniew, 2015). The five platforms - Airbnb, Couchsurfing, Homeaway, Housetrip, 9Flats - are described in order to identify their aim.

\section{$\square$ Platform: Airbnb}

Joe Gebbia and Brian Chesky were flat mate during their period in LA for college. They had the idea to transform their house in a bed\&breakfast but, without extra beds, they decided to use few airbeds, that is where the name "Airbnb" come from. The problem was understanding the reaction of people in front of strangers coming and living in their house. During an interview, Brian Chesky just said they believe that there would be no strangers. Airbnb is a global community based on trust and reliability; using it anybody can rent a room, an apartment, a villa or even a castle or a three-house as long as they need, all over the world and at any price point. It is really useful for owners, in order to monetize some extra space, but also for travelers, who want to travel saving some money and to interact with locals.

\section{Platform: Couchsurfing}

Couchsurfing is a global community of 14 million Csers who can find a couch in more than 200.000 cities, people who use it frequently are called "Couchsurfers", "CSers", or even "Surfers". The name means "jumping from a couch to another". Being part of this community means being part of something bigger: travelers share their life, experiences, habits, knowledges and even their couch with someone they do not know. 


\section{$\square$ Platform: Homeaway}

Homeaway is part of the HomeAway Group with VRBO, Vacation Rentals, Homeliday and a few more. Ten years later its foundation, Homeaway was bought by Expedia.it for $\$ 3.9$ billion. Every tourist is able to find the perfect home between 1.2 million homes in 190 countries all over the world. The visitor can choose any kind of location: a cabin, an apartment, a castle, a villa or even a barn or a farm house. Just like Airbnb, HomeAway is really useful not only for tourists but also for owners; if someone own an extra vacation house you can easily decide to rent it and gain some extra money.

\section{$\square$ Platform: Housetrip}

Housetrip is part of the TripAdvisor Rentals (TripAdvisor acquired HouseTrip in 2016), which means that every feedback is written by trusted and verified TripAdvisor guests. It's easy to find the perfect solution for any kind of vacation: small apartments for couples or big houses for entire families, solutions at the seaside or close to the mountains or in the countryside.

\section{Platform: 9Flats}

They almost have 60 thousand places travelers can rent all over the world. For the name the founders were looking for something short, easy to remember, functional and they had an idea, the CEO Stephan Uhranbacher in an interview said: "if I was really rich, I would not have only one place, I would have at least nine places all over the world" and that's where the name "9Flats" comes from. This company make sure to stand out in this market taking geographical focus: Germany, in this country they are known much better than any other competitor and it is a very great source of revenue.

Table 1: Description of the Platforms

\begin{tabular}{|c|c|c|c|c|}
\hline Platform & City & $\begin{array}{cc}\text { Year } & \text { of } \\
\text { Foundation } & \end{array}$ & Founders & Job \\
\hline Airbnb & $\begin{array}{c}\text { San } \\
\text { Francisco }\end{array}$ & 2008 & $\begin{array}{l}\text { Brian Chesky, } \\
\text { Joe Gennia and } \\
\text { Nathan } \\
\text { Blecharczyk }\end{array}$ & $\begin{array}{l}\text { Airbnb does not own any } \\
\text { house, room, apartment or } \\
\text { villa, it is a broker which } \\
\text { match owners with } \\
\text { travelers. Airbnb is one of } \\
\text { the biggest online } \\
\text { community, which helps } \\
\text { people feeling home during } \\
\text { a journey. }\end{array}$ \\
\hline Couchsurfing & $\begin{array}{c}\text { San } \\
\text { Francisco }\end{array}$ & 2004 & Casey Fenton & $\begin{array}{l}\text { It's a no-profit } \\
\text { community devoted to } \\
\text { connecting travelers with } \\
\text { locals. "Stay with Locals } \\
\text { and meet Travelers" is the } \\
\text { Couchsurfing slogan, } \\
\text { another online community. }\end{array}$ \\
\hline
\end{tabular}




\begin{tabular}{|c|l|l|l|l|}
\hline Homeaway & Austin & 2005 & $\begin{array}{c}\text { Brian Sharples } \\
\text { and Carl Sheperd }\end{array}$ & $\begin{array}{c}\text { It is a profit online } \\
\text { marketplace for vacation } \\
\text { rental and slogan is } \\
\text { "Get Away from it all". }\end{array}$ \\
\hline Housetrip & Lausanne & 2009 & $\begin{array}{l}\text { Arnaud } \\
\text { Bertrand and } \\
\text { Junjun } \\
\text { Bertrand }\end{array}$ & $\begin{array}{l}\text { Housetrip is a possible } \\
\text { alternative to hotels'room. } \\
\text { Housetrip is a synonym of } \\
\text { authenticity, safety, } \\
\text { credibility, convenience, } \\
\text { flexibility and cosines. } \\
\text { Housetrip does not own } \\
\text { any house, it is just a kind } \\
\text { of broker which match } \\
\text { owners with tourists, just } \\
\text { like Airbnb. }\end{array}$ \\
\hline 9Flats & Hamburg & 2011 & $\begin{array}{l}\text { It is a company working } \\
\text { in the peer-to-peer vacation } \\
\text { rental space mostly focused } \\
\text { on cities apartments. }\end{array}$ \\
\hline
\end{tabular}

Source: authors' elaboration

\section{Research Design}

\subsection{Methodology}

The aim of the research is to investigate the users' attitude toward online platforms and, how those platforms are changing the traveler's experience of people.

In the analysis, authors have taken into consideration five different platforms that are usually chosen by travelers to rent a room or a home for holidays: Airbnb, HomeAway, Housetrip, Couchsurfing and 9Flats. The platforms have different objectives as well as services offered to travelers; those differences become clear using them.

Consequently, the analysis was split into two different moment: the first one was dedicated to identify the major differences between platforms through the direct use of platforms' services and, the second one was directed to travelers that were asked to answer to a questionnaire.

The questionnaire was created in February 2017 and sent between March and April 2017; it was structured in different section in order to cover different areas of interest.

The first section was the fact-finding section and, in this part, people were asked to think about their travels: why, how, with who and how often they travel, as well as how they usually organize the journey, and if they were aware about the existence of the platforms selected (Airbnb, Couchsurfing, HomeAway, Housetrip and 9Flats).

The second section was focused on the understanding of the usefulness of those services and, in particular on the satisfaction that travelers have in using them. The main purpose of the section was to catch the level of influence of those services on the organization of the travel and, how this influence affects travelers' mood.

Finally, the third section was dedicated to collect travelers' personal data: age, gender, job position and provenience.

Data were analyzed using both description analysis and correlation analysis. 


\subsection{Platforms' Comparison}

All the platforms analyzed are used by travelers to book a room or a home for holidays but, each platform seem to serve a different segment of travelers. In fact, analyzing the website's structure authors have identified some differences that can influence the travelers' decision; differences can be summarized as: enrollment on the platform; minimum number of days' reservation; range of offers; the presence of an app and, the level of "sharing". Authors describe the main differences between the five platforms taking into consideration each element previously identified.

The first element is the enrolling. This point is important because for many person it can represents a reason to search for another solution: the privacy is a delicate theme and, people prefers to navigate in the website before register their data. If travelers want to rent a couch on Couchsurfing they have to enroll instantly, on the other hand, if they want to book a room or an entire house using Housetrip, HomeAway, 9Flats and Airbnb, they are able to enroll and login later and, they can also use their Facebook profile. The second element is represented by the days of staying. If travelers are looking for an accommodation for one or two days are forced to use some platforms instead of others. In fact, a really big difference between Airbnb and HomeAway is that in HomeAway it is not possible to rent a house for only two or three days, customers need to stay longer, instead, Airbnb let customers book anything also for one day. The third element is the vastness of the offer. In this case, travelers have a propensity for the platform that can assure both quality/price and number of offers. HomeAway has over 1 million vacation rental solutions in 190 countries: Airbnb has almost 800,000 solutions also in 190 countries; Couchsurfing has couches in 200.000 cities all over the world and 9Flats has almost 60 thousand places globally. The fourth element is the existence of an App. Nowadays people are used to consult smartphones as a first source of information: the presence of an App can help in spreading the platforms between travelers, the App could represent a relevant strategy. Three out of five platforms analyzed has an application (Airbnb, HomeAway and Couchsurfing). Finally, the last element identified is the level of "sharing". If someone decide to use Couchsurfing cannot choose to share or not to share the space with someone else, it is the owner that decide, this is why on Couchsurfing there is not an official booking or payment process. In fact, the main difference between Couchsurfing and all the other platforms is that owners cannot gain extra money sharing couches. HomeAway and Housetrip are the perfect alternatives to hotels rooms, but if people are looking for something more casual and peculiar, probably they use Airbnb, Couchsurfing and 9Flats. It is really up to the travelers' attitude to decide which platform is the best in order to escape from the daily routine and organize the travel. It is important to underline that this vast option represents a relevant benefit for travelers, because anybody would be able to find the perfect solution to satisfy his/her own needs.

\subsection{Data Analysis}

Around 200 answers were gathered from all over Italy; the majority of respondents were women, $60.5 \%$, and only the $39.5 \%$ were men.

Even if the majority of answers are from 18-28 years old people, the sample is pretty heterogeneous, as it is possible to observe from the table below. 
Also, professions are pretty heterogeneous: in fact, there are $44.6 \%$ students, $30.1 \%$ employees, $10.9 \%$ freelances, $5.2 \%$ entrepreneur and $9.3 \%$ "others" which include retirees or artists.

Table 2: Description of the Sample

\begin{tabular}{ll}
\hline Gender & $\%$ \\
\hline Female & 60,5 \\
Male & 39,5
\end{tabular}

\begin{tabular}{ll}
\hline Age & $\%$ \\
\hline 17 & 2 \\
$18-28$ & 47 \\
$29-37$ & 15 \\
$38-45$ & 16 \\
$46-55$ & 10 \\
$56-65$ & 4 \\
$>66$ & 6
\end{tabular}

\begin{tabular}{ll}
\hline Profession & $\%$ \\
\hline Students & 45 \\
Employee & 30 \\
Professional & 11 \\
Entrepreneur & 5 \\
Other & 9 \\
& \\
\end{tabular}

Source: authors'eleboration.

The respondents are living in Italy and are included regions of the South (Sicily, Sardinia, Campania, etc.), North (Piedmont, Lombardy, Liguria, etc.) and Centre (Tuscany, Lazio, etc.) of the country.

Submitting the survey, authors found out that the service most used in Italy is Airbnb, in fact the $74.4 \%$ replied "Yes" to the question "Have you ever used Airbnb?". However, the $90.7 \%$ of the sample confirmed to know Airbnb.

Instead, the less used and known is 9Flats, which is weird because it is the only European service present in the list. Only the $14,8 \%$ of people said that they have used 9Flats at least ones and, the $73.3 \%$ said that they have never heard about it before.

Table 3: Usage of Services

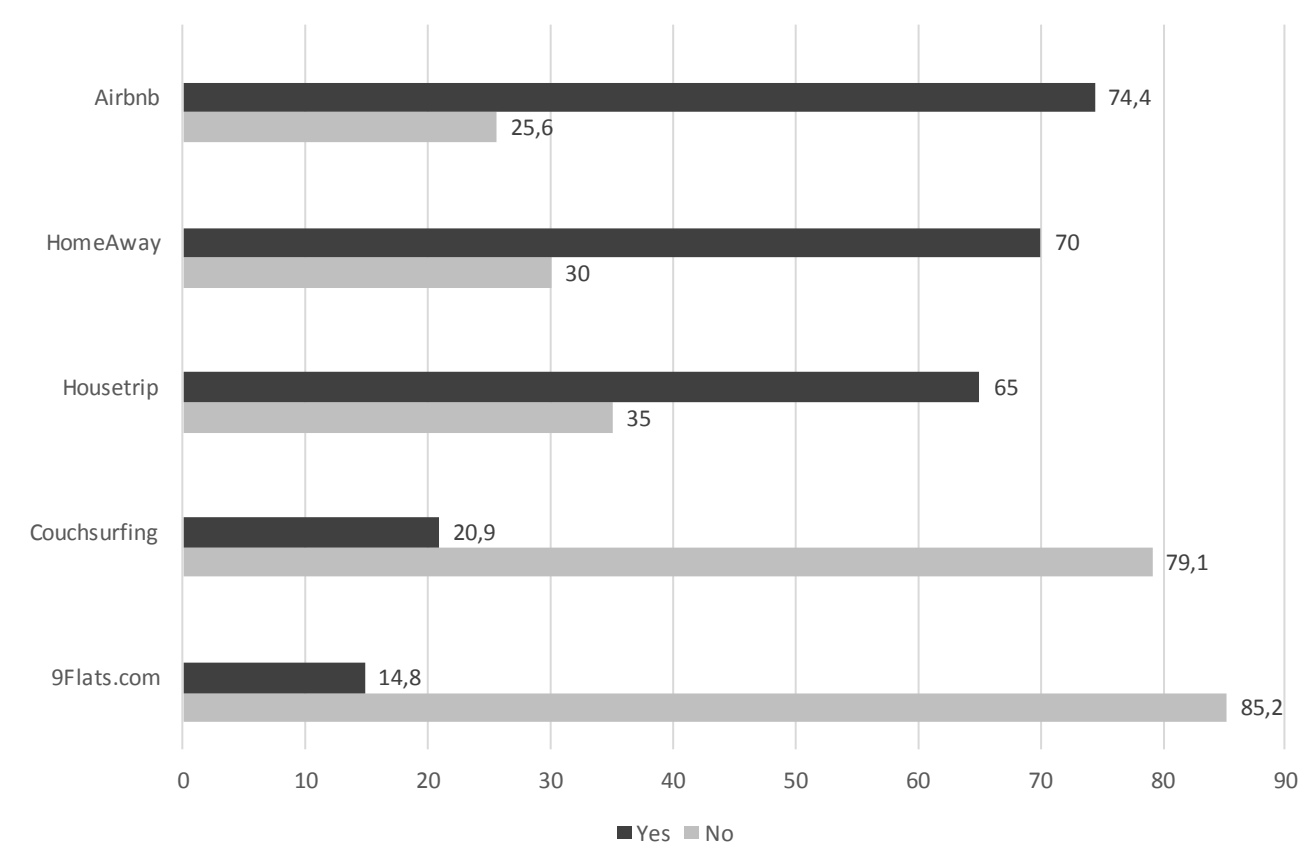

Source: authors' elaboration 
In order to understand if customers feel happy and satisfied after using these services, authors have analyzed the mean value of the satisfaction for each platform (on a scale from 1 to 7 ):

Table 4: Mean Value of Satisfaction for each Platform

\begin{tabular}{|l|l|}
\hline Airbnb & 5,5 \\
\hline HomeAway & 4,3 \\
\hline HouseTrip & 3,6 \\
\hline CouchSurfing & 3,4 \\
\hline 9Flats & 3,2 \\
\hline
\end{tabular}

Source: authors' elaboration

The satisfaction gained by Airbnb is pretty high, instead the one gained from Couchsurfing and 9Flats it is not. Authors noticed that there is a connection between the happiness perceived by using those services and, the percentage of customers that are using them; in fact, the most used service - Airbnb - is also the one which pleased the most; 9Flats which is the less used platform is also the less pleased. Analyzing the outcomes, authors found out that there is a link between users' age and the effective use of each platform:

- Airbnb: most of the users are between 18 and 28 years old. A really interesting thing about Airbnb for each age class more than the 50\% has used the service at least once in his/her life.

- Couchsurfing: most of the users are between 38 and 45 years old. In this case, the age class between 56-66 years old has never used Couchsurfing.

- HomeAway: most of the users are between 38 and 45 years old $(54,5 \%)$; in this case, each age class has used at least once the service, but in percentage they represent the minority of the sample $(<35 \%$ for each age class).

- HouseTrip: most of the users are between 38 and 45 years old $(33,33 \%)$; the youngest age class ( $<17$ years old) has declared to have never used the service.

- $\quad$ 9Flats: most of the users are the youngest one ( $<17$ years old) and $100 \%$ of $56+$ years old people said that they never used 9Flats.

Table 5: Age Classes Using the Services

\begin{tabular}{|l|l|l|l|l|l|}
\hline Age & AIRBNB & COUCHSURFING & HOMEAWAY & HOUSETRIP & 9FLATS \\
\hline $\mathbf{1 1 7}$ & $66,6 \%$ & - & $33,3 \%$ & - & $\mathbf{3 3 , 3 3 \%}$ \\
\hline $\mathbf{1 8 - 2 8}$ & $\mathbf{8 5 \%}$ & $16,49 \%$ & $24,74 \%$ & $10,30 \%$ & $9,28 \%$ \\
\hline $\mathbf{2 9 - 3 7}$ & $66,6 \%$ & $23,33 \%$ & $33,33 \%$ & $23,33 \%$ & $26,66 \%$ \\
\hline $\mathbf{3 8 - 4 5}$ & $81,82 \%$ & $\mathbf{3 3 , 3 3 \%}$ & $\mathbf{5 4 , 5 5 \%}$ & $\mathbf{3 3 , 3 3 \%}$ & $18,18 \%$ \\
\hline $\mathbf{4 6 - 5 5}$ & $57,89 \%$ & $26,32 \%$ & $31,58 \%$ & $21,05 \%$ & $26,32 \%$ \\
\hline $\mathbf{5 6 - 6 6}$ & $62,5 \%$ & - & $12,5 \%$ & - & - \\
\hline $\mathbf{6 6 +}$ & $16,67 \%$ & $8,33 \%$ & $8,33 \%$ & $8,33 \%$ & - \\
\hline
\end{tabular}

Source: authors' elaboration 
In general, it is possible to notice that the majority of the users are between 17 and 45 years old, while older people (between 46 and 66+) are not really used to organize their vacation on these platforms, especially on 9Flats, HouseTrip and Couchsurfing. The heart of the collaborative consumption phenomenon is mostly represented by young people, because of their level of confidence with technology and their propensity to exploit this kind of tools.

Analyzing the reasons why these platforms have a positive impact on people, authors noticed that the three main motivations are: save money $(54.5 \%)$; share knowledge and experiences with other people (21\%); make new friends $(9.7 \%)$.

Authors in this survey used two variables, such as: savings and organizational simplification, in order to measure travelers' happiness and satisfaction.

Savings money and easier organization are two of the key aspects able to improve the travelers' happiness and satisfaction. In fact, calculating the Pearson Correlation Coefficient between these two aspects for each platform, authors found out that there is a pretty strong connection $(0,37<\mathrm{x}<0,6)$ for platforms as Airbnb, HouseTrip and HomeAway; for apps as 9Flats and Couchsurfing it is a little bit lower $(0,1<\mathrm{x}<0,2)$.

This means that higher is the chance to save money and the organizational simplification, the higher will be the happiness and the satisfaction gained by customers.

\section{Conclusion}

Tourism came out to be one of the sector more involved in the sharing economy and in the collaborative consumption phenomenon, in fact it is possible to customize packages, organize travels without agencies or physical intermediaries.

Sharing and collaborative consumption, based on trading and swapping, has given the possibility to new companies to emerge and serve travelers as they need to.

The mass tourism industry is gone, which means that access is the new ownership (Rifkin, 2000): people do not have to own a car in order to move or a house in order to go on a vacation; they can just share or bartering or lending or even trading things. This is the key aspect of the new online and globalized market.

The tourism industry is considered a really innovative sector, which is why the collaborative consumption is spreading all over this sector (Ivanova, 2015).

Travelers and owners started using platforms such as Airbnb, HouseTrip, HomeAway, 9Flats or Couchsurfing to satisfy their practical needs, for example meeting people, helping out, gaining some extra money (owners) or saving money travelling (travelers), etc.

When people buy something, do not simply buy the product or the service, they buy the output which represents everything that will be satisfied by the product or the service. So, people are hiring a product or a service in order to get a job done (Christensen et al, 2016) and, the real problem for companies is to identify what customers want (Ulvick, 2016). In the tourism sector, travelers are now looking for social and emotional experiences, as well as economic advantages.

Through this research authors' main objective was investigate the users' attitude toward online platforms and, if those platforms are really changing the approach toward the travel's experience.

The majority of people - without platforms such as Airbnb, Couchsurfing, Homeaway, Housetrip and 9Flats - would now feel incomplete, disoriented and, 
worried, above all young people. This is an important sign about how the technology is influencing the way to live new experiences.

Those platforms are like a reference point for travelers and have a strong influence on their freedom in choosing how to live vacation and the travel itself.

The alternative is to use the most common website or agencies and this is perceived as an "institutional" obligation, but traditional channels are almost bypassed.

Almost all the platforms are well known by people and, the main differences between them are linked to the age of the users: some platforms are more in line with the needs of young people while others are used by adults. Moreover, it seems that everybody is conscious about which is the level of offer and the added value given by each platform.

Companies/platforms understood that people had unsatisfied needs like saving money, meeting locals, sharing knowledge and, that the technology can change the traditional path toward the travel's organization. These aspects, that have a strong influence on travelers' mood, are satisfied by online platforms like Airbnb, HomeAway, HouseTrip, Couchsurfing and 9Flats.

Although if it is a first study and it has some limitation, authors think that this outcome draws attention to the importance and potential of these services, as well as on a market that is changing. To become competitive in the tourism sector, it is necessary to understand the influence that the collaborative consumption can have on the level of people's satisfaction.

\section{Bibliography}

Arente, H., \& Kiiski, V. (2006). Tourist identity expression through postmodern con- sumption: A focus on the home-exchange phenomenon. Masters thesis. Göteborg University, Gothenburg, Sweden

Algar, R. (2007). Collaborative Consumption, Leisure Report, April Edition.

Bernardi, M. (2015). Un'introduzione alla Sharing Economy. Ebook, Fondazione GianGiacomo Feltrinelli.

Bloch, M. and Segev, A. (1996), The Impact of Electronic Commerce on the Travel Industry, available at: www.haas.berkeley.edu/citm/publications/papers/wp-1017.html

Botsman, R. (2015). Defining The Sharing Economy: What Is Collaborative Consumption-And What Isn't. Fastcoexist.com, 27.

Botsman, R. (2013), The Sharing Economy Lacks A Shared Definition, available on: http://www.collaborativeconsumption.com/2013/11/22/the-sharing-economy-lacks-a-shareddefinition/

Botsman, R., \& Rogers, R. (2011). What's mine is yours: how collaborative consumption is changing the way we live. London: Collins.

Botsman, R., \& Rogers, R. (2010). Beyond zipcar: Collaborative consumption. Harvard Business Review, 88(10), 30.

Brondoni, S.M. (2016). Global Tourism Management. Mass, Experience and Sensations Tourism, Symphonya. Emerging Issues in Management (symphonya.unimib.it), 1, 7-24.

http://dx.doi.org/10.4468/2016.1.02brondoni

Brondoni S.M. (2002). Global Markets and Market-Space Competition, Symphonya. Emerging Issues in Management (symphonya.unimib.it), 1, 28-42.

http://dx.doi.org/10.4468/2002.1.03brondoni

Brondoni, S.M. (2014) Global Capitalism and Sustainable Growth. From Global Products to Network Globalisation, Symphonya. Emerging Issues in Management (symphonya.unimib.it), 1, 10-31

http://dx.doi.org/10.4468/2014.1.02brondoni 
Brondoni, S.M., \& Pironti, M. (2015). Ouverture de 'Design Management, Product Engineering and Global Competition', Symphonya. Emerging Issues in Management, 2.

http://dx.doi.org/10.4468/2015.2.01ouverture

Buhalis, D., \& Law, R. (2008). Progress in information technology and tourism management: 20 years on and 10 years after the Internet-the state of eTourism research. Tourism Management, 29(4), 609-623.

Christensen, C. M., Hall, T., Dillon, K., \& Duncan, D. (2016). Know Your Customers' Jobs to be Done. Harvard Business Review, 9, 54-62.

De Carlos, P., Araújo, N., \& Fraiz, J. A. (2016). The New Intermediaries Of Tourist Distribution: Analysis Of Online Accommodation Booking Sites. International Journal of Management Science \& Technology Information, (19).

Duffy, S. Collaborative Consumption and its implications for consumer behaviour. Accessed: http://www.brandba.se/blog/cocollaborativeconsumptionconsumerbehavior-ammermann

Eckhard, G. M., Bardhi, F. (2015), The Sharing Economy Isn't About Sharing at All, Harvard Business Review Online, January 28.

Forno, F., \& Garibaldi, R. (2015). Sharing Economy in Travel and Tourism: The case of homeswapping in Italy. Journal of Quality Assurance in Hospitality \& Tourism, 16(2), 202-220. http://dx.doi.org/10.1080/1528008X.2015.1013409

Franch, M., \& Martini, U. (2002, January). Il ruolo delle tecnologie per l'informazione e la comunicazione nello sviluppo delle politiche di marketing delle destinazioni turistiche alpine. In Collesei, U. and Andreani, JC Congresso Internazionale Tendances du Marketing. Parigi: ESCP-EAP (pp. 25-26).

Geyer-Schulz, A. \& Meyer-Waarden, L. (2014). Customer \& Service Systems. KIT Scientific Publishing, Vol. 1, No. 1, S. 1-17. https://doi.org/10.5445/KSP/1000038784

Grit, A., \& Lynch, P. (2011). An analysis of the development of home exchange organisations. Research in Hospitality Management, 1(1), 1-7. https://doi.org/10.2989/RHM.2011.1.1.5.1095

Hamari, J., Sjöklint, M., \& Ukkonen, A. (2016). The sharing economy: Why people participate in collaborative consumption. Journal of the Association for Information Science and Technology, 67(9), 2047-2059. https://doi.org/10.1002/asi.23552

Heath, E. (2001). Globalisation of the Tourism Industry: Future Trends and Challenges for South Africa, SAJEMS NS, (4) 3, 542-569.

Ivanova, M. G. (2015). Sharing Economy: Bulgarian Tourism Industry Perspective, Proceedings of International Conference "Tourism in the age of transformation". Varna, University of EconomicsVarna, (pp. 479-488)

Kade, M. (2015). A conversation around connecting humanity to themselves and each other. Aspire Magazine

Maci, L. (2016). Sharing economy, cosa è (e perché è difficile dire cosa è). Economy up

McMahon, E. T. (2015). Ten Principles for Responsible Tourism. Urban Land The Magazine of the Urban Land Institute. Retrieved from http://urbanland. uli. org/economy-markets-trends/tenprinciples-responsible-tourism.

Molz, J. G. (2013). Social networking technologies and the moral economy of alternative tourism: The case of couchsurfing. org. Annals of tourism research,43, 210-230. https://doi.org/10.1016/j.annals.2013.08.001

Pearce, D. G., \& Schott, C. (2005). Tourism distribution channels: The visitors' perspective. Journal of Travel Research, 44(1), 50-63. https://doi.org/10.1177/0047287505276591

Peeters, P., Dijkmans, C., Mitas, O., Strous, B., \& Vinkensteijn, J. (2015). Research for tran committee-tourism and the sharing economy: challenges and opportunities for the eu. Policy Department Structural and Cohesion Policies, European Parliament.

Pellicelli, G. (2007). Il marketing internazionale. Etas.

PwC (2014). The Sharing Economy: global analysis 2014

Rifking, J. (2000). L'era dell'accesso. La rivoluzione della new economy. Milano, Mondadori.

Salvioni, D. M. (2016). Hotel Chains in the Sharing Economy in Global Tourism, Symphonya. Emerging Issues in Management (symphonya.unimib.it), 1, 31-44. http://dx.doi.org/10.4468/2016.1.04salvioni

Schor, J. (2016). Debating the sharing economy. Journal of Self-Governance and Management Economics, 4(3), 7-22. 
Turban E., J. Lee, D. King \& M. H. Chung (2000). Electronic Commerce: A Managerial Perspective, Upper Saddle River, Prentice Hall.

Ulwick W. A. (2016). Jobs to be done: Theory To Practice. Idea Bite Press.

Wang, C., \& Zhang, P. (2012). The evolution of social commerce: The people, management, technology, and information dimensions. Communications of the Association for Information Systems, 31(1), 105-127.

Zervas, G., Proserpio, D., \& Byers, J. W. (2014). The rise of the sharing economy: Estimating the impact of Airbnb on the hotel industry. Journal of Marketing Research.

Zbigniew, G. (2015), 8 Things to Use in "Jobs to be Done" Framework For Product Development, available on: https://medium.com/@zbigniewgecis/8-things-to-use-in-jobs-to-be-done-frameworkfor-product-development-4ae7c6f3c30b 